\title{
Double water-clear cell parathyroid adenoma: a case report and literature review
}

\author{
Chia-An Yang ${ }^{1)}$, Jiun-Lu Lin ${ }^{2}$, Shuen-Han Dai ${ }^{3)}$ and Shih-Ping Cheng ${ }^{1)}$ \\ 1) Department of Surgery, MacKay Memorial Hospital and Mackay Medical College, Taipei 104215, Taiwan \\ 2) Division of Endocrinology and Metabolism, Department of Internal Medicine, MacKay Memorial Hospital and Mackay Medical \\ College, Taipei 104215, Taiwan \\ 3) Department of Pathology, MacKay Memorial Hospital and Mackay Medical College, Taipei 104215, Taiwan
}

\begin{abstract}
Water-clear cell parathyroid adenoma is an uncommon cause of primary hyperparathyroidism. Herein, we report an interesting case of a 56-year-old man who presented with weight loss, bone pain, fatigue, and a palpable right neck mass. Laboratory tests indicated hypercalcemia, elevated parathyroid hormone (PTH) levels, and normal thyroid function. Further examinations detected osteoporosis and kidney stones. The ultrasound of neck revealed bilateral extrathyroidal tumors, which were sestamibi-avid. The patient underwent resection of the large right inferior and left inferior parathyroid tumors. Histopathology revealed a double water-clear cell parathyroid adenoma. His serum calcium and PTH levels normalized after surgery. The literature review identified 37 cases of water-clear cell parathyroid adenoma between 1985 and 2021. The median age at diagnosis was 56 years. Classic complications were common, including nephrolithiasis in nine and skeletal presentations in 10 patients. Before surgery, the median calcium and PTH levels were $12.0 \mathrm{mg} / \mathrm{dL}$ and $290 \mathrm{pg} / \mathrm{mL}$, respectively. Overall, $89 \%$ were localized on ultrasonography, and $60 \%$ were positive on scintigraphy. Four patients had double adenomas. The median maximum diameter was $3.8 \mathrm{~cm}$, and the median weight of the resected adenoma was $5.27 \mathrm{~g}$. In summary, water-clear cell parathyroid adenoma has certain unique features. These include larger tumor size, relatively indolent biochemical profile, high prevalence of complications and nonspecific symptoms, an isoechoic appearance on ultrasonography, and reduced scintigraphic sensitivity.
\end{abstract}

Key words: Water-clear cell, Parathyroid, Double adenoma, Primary hyperparathyroidism

PRIMARY HYPERPARATHYROIDISM is the most common cause of hypercalcemia [1]. The underlying pathophysiology is the loss of feedback suppression of serum calcium upon the synthesis and secretion of parathyroid hormone (PTH) owing to increased parathyroid cell mass and/or reduced expression of the calciumsensing receptor. The diagnosis of hyperparathyroidism is based on hypercalcemia and non-suppressed PTH levels.

In $80 \%$ of cases of primary hyperparathyroidism, excessive secretion of PTH results from a solitary parathyroid adenoma. It has been documented that four-gland hyperplasia accounts for $10 \%-15 \%$ of cases, multiple adenomas in $5 \%$, and parathyroid cancer in less than $1 \%$. Histologically, parathyroid adenomas are composed of varying proportions of cell types that make up the normal parathyroid gland, but there is a typical predominance of

Submitted Sep. 27, 2021; Accepted Nov. 29, 2021 as EJ21-0590 Released online in J-STAGE as advance publication Jan. 6, 2022 Correspondence to: Shih-Ping Cheng, MD, PhD, Department of Surgery, MacKay Memorial Hospital, 92, Chung-Shan North Road, Section 2, Taipei 104215, Taiwan.

E-mail:surg.mmh@gmail.com chief cells [2]. Uncommon variants include oxyphil adenomas, lipoadenomas, and water-clear cell adenomas.

Water-clear cells are characterized by optically clear cells with abundant foamy-to-granular cytoplasm, which is attributed to the presence of numerous small vacuoles derived from the Golgi apparatus [2]. Water-clear cell parathyroid adenoma is a rare cause of primary hyperparathyroidism [3]. In this report, we present a patient with double water-clear cell parathyroid adenoma and review the literature highlighting the unique features of this entity.

\section{Case Report}

A 56-year-old man was noted to have persistently high serum calcium levels on regular blood tests. His medical history was remarkable for essential hypertension and chronic tophaceous gout treated with medications. He reported a weight loss of $3 \mathrm{~kg}$, intermittent bone pain, and fatigue for a few months. He had no voice changes, neck pain, or swallowing symptoms. There was no radiation exposure in the past, and neither a family history for multiple endocrine neoplasia or neurofibromatosis. 
Physical examination revealed a firm, non-tender mass in the right thyroid region. The ultrasound of neck showed well-defined homogeneous extrathyroidal tumors with similar or slightly decreased echogenicity compared to the thyroid parenchyma at the bilateral lower neck (Fig. 1A and 1B). The thyroid gland, though otherwise unremarkable, was compressed by the tumor. The nodules measured $4.7 \times 3.1 \times 3.6 \mathrm{~cm}$ on the right side and $2.8 \times 1.8 \times 1.8 \mathrm{~cm}$ on the left. There was no evidence of tumor invasion to adjacent structures or lymphadenopathy. Fine-needle aspiration biopsy was not performed as the tumors were suspected to be of parathyroid origin.

Laboratory tests showed a serum calcium level of $12.7 \mathrm{mg} / \mathrm{dL}$ (reference range $8.9-10.3 \mathrm{mg} / \mathrm{dL}$ ), serum phosphorus of $2.1 \mathrm{mg} / \mathrm{dL}$ (reference range 2.7$4.5 \mathrm{mg} / \mathrm{dL}$ ), and intact PTH level of $936.94 \mathrm{pg} / \mathrm{mL}$ (reference range 10.00-60.00 pg/mL). He was euthyroid with a TSH level of $0.75 \mu \mathrm{lU} / \mathrm{mL}$ (reference range 0.25 $4.00 \mu \mathrm{lU} / \mathrm{mL}$ ) and calcitonin level of $14.00 \mathrm{pg} / \mathrm{mL}$ (reference range $<18.2 \mathrm{pg} / \mathrm{mL}$ ). Though his chest X-ray was essentially normal, the plain abdominal radiographs revealed radiopaque lesions over the bilateral renal shadows. Subsequent renal ultrasonography confirmed the presence of bilateral kidney stones. Dual-energy Xray absorptiometry disclosed bone mineral density of $0.579 \mathrm{~g} / \mathrm{cm}^{2}$ with a T-score of -2.6 and Z-score of -1.3 , corresponding to osteoporosis. Dual-phase Tc-99m sestamibi scintigraphy with three-dimensional assessment using single-photon emission computed tomography (SPECT) was performed. Increased radioactivity was observed in the right and left lower thyroid regions (Fig. 1C), corresponding to the two enlarged parathyroid glands seen on ultrasound.

The patient was admitted with an initial diagnosis of a double parathyroid adenoma. Bilateral neck exploration was performed through a low-collar incision under general anesthesia. Large parathyroid tumors with no adhesion to the thyroid were resected from the inferior poles of the bilateral thyroid lobes. The superior parathyroid glands on both sides appeared to be normal.

Gross examination of the resected tumors revealed tan-white lesions covered with a thin capsule (Fig. 2A). The tumor on the right side was $5.6 \times 3.5 \times 3.0 \mathrm{~cm}$ in size and weighed $32 \mathrm{~g}$; the other on the left side measured $2.7 \times 2.0 \times 1.5 \mathrm{~cm}$ and had a weight of $4.3 \mathrm{~g}$.
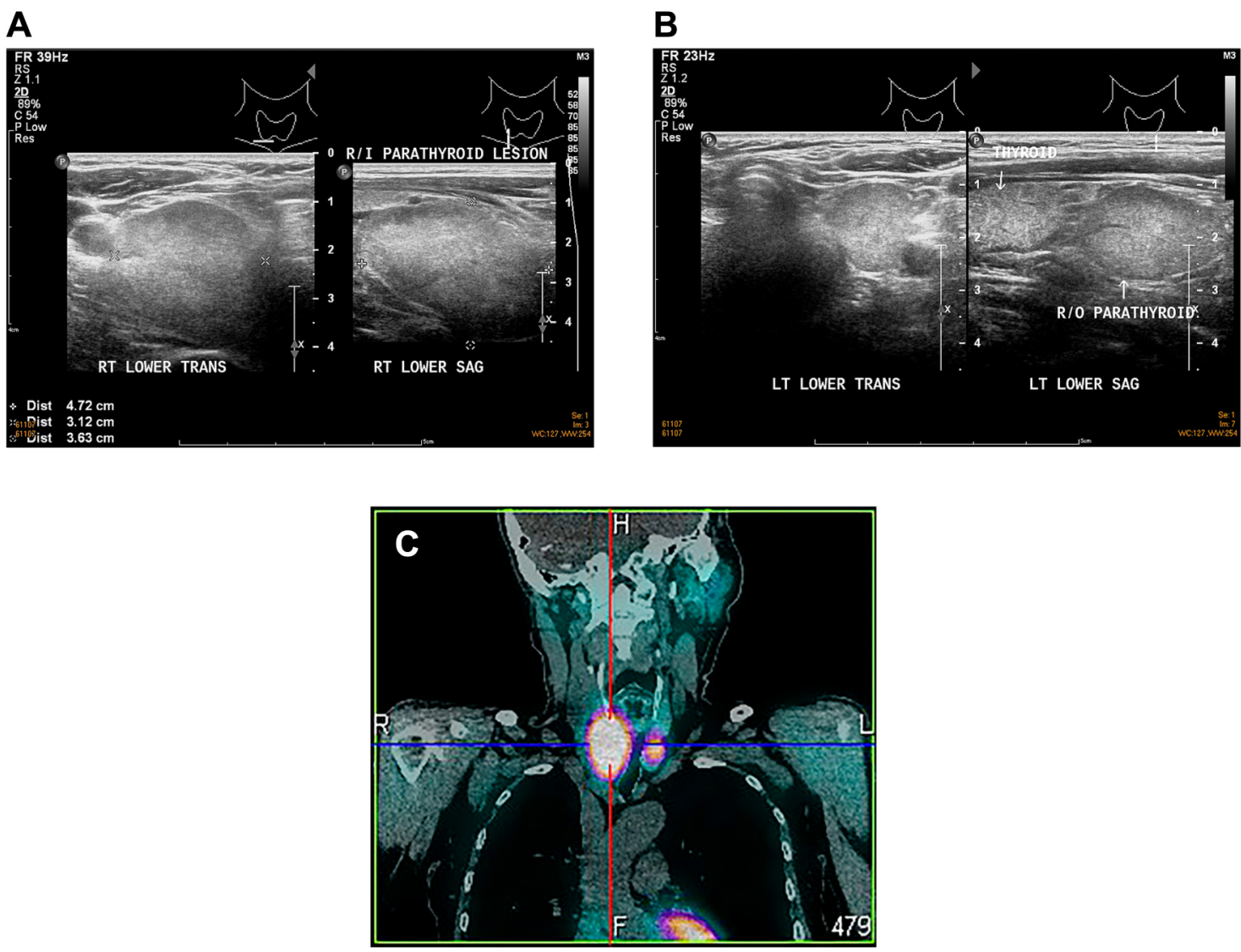

Fig. 1 Preoperative imaging studies of the patient with double water-clear cell parathyroid adenoma. (A) Transverse and longitudinal scan of the right extrathyroidal tumor. (B) Transverse and longitudinal scan of the left extrathyroidal tumor. (C) Tc- $99 \mathrm{~m}$ sestamibi SPECT imaging. 

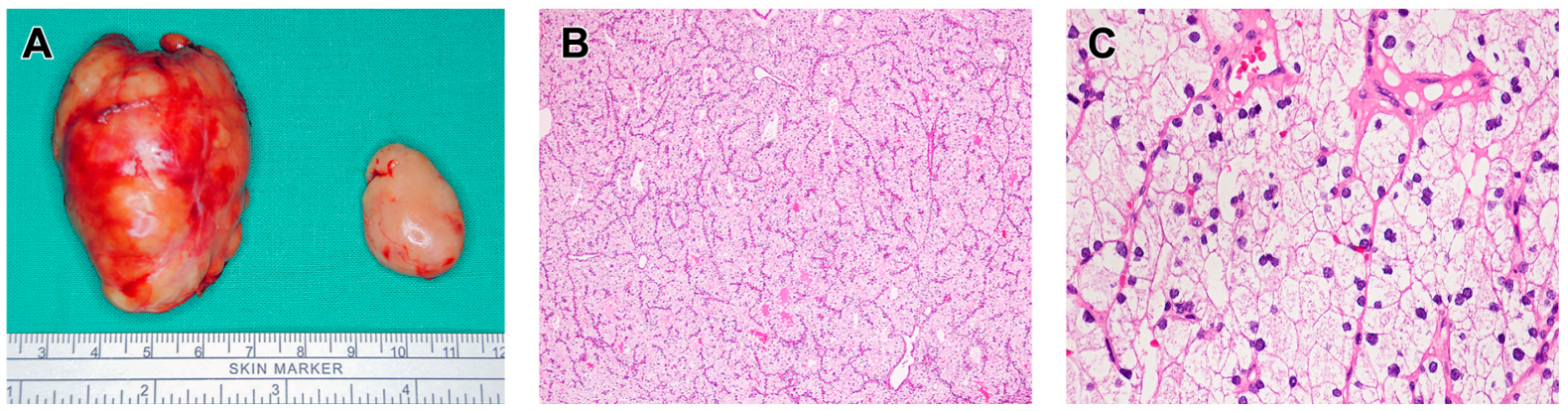

Fig. 2 Pathologic imaging of double water-clear cell parathyroid adenoma. (A) Macroscopic view of double parathyroid adenoma. (B) Overview of the right parathyroid tumor (H\&E, original magnification 40×). (C) High-power view of the left parathyroid tumor (H\&E, original magnification 400×).

Microscopically, both tumors were composed exclusively of uniform, large, clear cells without intervening fat cells or necrosis (Fig. 2B). No rim of compressed normal parathyroid tissue was identified at the tumor periphery. At high magnification, the cytoplasm was finely vacuolated (Fig. 2C). The nuclei of tumor cells exhibited no pleomorphism or atypical mitosis.

The patient recovered uneventfully and was discharged from the hospital on postoperative day 2. His intact PTH level dropped to $15.54 \mathrm{pg} / \mathrm{mL}$ after the surgery, and he remained normocalcemic during follow-up.

\section{Literature Review}

A systematic search of relevant literature published between January 1985 and August 2021, identified 37 cases of water-clear cell parathyroid adenoma, including the present case (Table 1). The median age at diagnosis was 56 years (range, $18-81$ years). Twenty-seven (73\%) were women and 10 were men. Classic complications were common. Nine patients were diagnosed with nephrolithiasis, and 10 patients had fragility fractures, brown tumors, osteoporosis, or osteopenia. Two patients had pancreatitis. The majority of others presented with nonspecific symptoms such as fatigue, muscle aches, bone pain, abdominal pain, depression, and lethargy.

Before surgery, the median calcium and PTH levels were $12.0 \mathrm{mg} / \mathrm{dL}$ and $290 \mathrm{pg} / \mathrm{mL}$, respectively. Imaging localization studies were performed in some of the patients. Most adenomas $(25 / 28,89 \%)$ were localized by ultrasonography. Interestingly, only $60 \%(15 / 25)$ of the patients had positive scintigraphy results and these had higher preoperative PTH levels (Mann-Whitney $U$ test, $p=0.027)$ and heavier or larger parathyroid adenomas $(p=0.001$, Fig. 3A).

Four patients had double parathyroid adenomas, and 33 had a single adenoma. Among 41 adenomas, 14 (34\%) were on the right side, and $26(63 \%)$ were on the left. One ectopic adenoma was found in the posterosuperior mediastinum. All patients with double adenomas had a crossed bilateral distribution. Water-clear cell parathyroid adenoma most frequently occurred in the left inferior parathyroid gland (16/41, 39\%).

The tumor size of water-clear cell parathyroid adenomas was relatively large compared to that of classic parathyroid adenomas. The median maximum diameter in the pooled analysis was $3.8 \mathrm{~cm}$ (range, $0.8-6.8$ ). The median weight of the resected adenoma was $5.27 \mathrm{~g}$ (range, 0.2736.3). Preoperative calcium levels did not correlate with PTH levels (Spearman rank correlation, $p=0.295$ ) or adenoma weight ( $p=0.551$, Fig. 3B). Nonetheless, it was noted that preoperative PTH levels were closely correlated with size (Spearman $\rho=0.659, p<0.001$ ) and weight $(\rho=0.727, p<0.001)$ of the adenoma. Adenoma size and weight were highly correlated ( $\rho=0.904, p<$ 0.001, Fig. 3C).

\section{Discussion}

Water-clear cell hyperplasia of the parathyroid glands was described as early as 1934. However, for reasons largely unknown, this type of hyperplasia has gradually disappeared in recent times [4]. In contrast, sporadic reports of water-clear cell adenomas are increasingly getting documented in the literature.

In our literature review, two series that compared the clinical and biochemical features between chief cell adenomas and clear cell adenomas were excluded because of the lack of individual information [5, 6]. It was considered that Kovacs and colleagues reported the first case of water-clear cell parathyroid adenoma [7]. Nonetheless, our survey revealed that the case described by Stout is better classified as double adenoma instead of hyperplasia in which normal right inferior parathyroid tissue was confirmed by a frozen section [8]. We also included an additional case that was previously classified as 
Table 1 Summary of cases reported in literature on water-clear cell parathyroid adenoma

\begin{tabular}{|c|c|c|c|c|c|c|c|c|c|c|c|}
\hline First author (year) & $\begin{array}{l}\text { Age } \\
\text { (year) }\end{array}$ & Sex & Presentations & $\begin{array}{l}\text { Calcium } \\
(\mathrm{mg} / \mathrm{dL})\end{array}$ & $\begin{array}{c}\text { PTH } \\
(\mathrm{pg} / \mathrm{mL})\end{array}$ & Ultrasound & Scintigraphy & $\begin{array}{c}\text { Adenoma } \\
\text { No. }\end{array}$ & Location $^{\mathrm{a}}$ & $\begin{array}{l}\text { Diameter } \\
\quad(\mathrm{cm})\end{array}$ & $\begin{array}{l}\text { Weight } \\
(\mathrm{g})\end{array}$ \\
\hline Stout (1985) [8] & 46 & $\mathrm{~F}$ & Nephrolithiasis & 11.6 & 21 & & & 2 & RS LS & 3.8 & 5.2 \\
\hline Kovacs (1994) [7] & 48 & M & Nephrolithiasis & 11.8 & & & & 1 & LI & & \\
\hline $\begin{array}{l}\text { Grenko (1995) } \\
\text { [21] }\end{array}$ & 40 & M & Fatigue, leg cramps & 11.3 & 945 & & & 1 & RS & 5 & 7.6 \\
\hline $\begin{array}{l}\text { Begueret (1999) } \\
\text { [22] }\end{array}$ & 73 & M & Nephrolithiasis & 13.8 & 207 & & & 1 & LI & 2.8 & \\
\hline $\begin{array}{l}\text { Dundar (2001) } \\
\text { [23] }\end{array}$ & 43 & $\mathrm{~F}$ & Fracture & 13.3 & 1,667 & + & - & 1 & $\operatorname{IT}(\mathrm{L})$ & 6 & \\
\hline Kuhel (2001) [12] & 56 & $\mathrm{~F}$ & Osteopenia & 13.2 & 52 & + & - & 2 & RS LS & 2.8 & 2.2 \\
\hline Kanda (2004) [17] & 52 & $\mathrm{~F}$ & $\begin{array}{l}\text { Nephrolithiasis, } \\
\text { gastric ulcer }\end{array}$ & 11.7 & 643 & + & + & 1 & LI & 6.8 & 15.4 \\
\hline Prasad (2004) [24] & 40 & $\mathrm{~F}$ & Osteopenia & 12.4 & 346 & & & 1 & LS & 3 & 4.2 \\
\hline $\begin{array}{l}\text { Kodama (2007) } \\
{[19]}\end{array}$ & 18 & F & Nephrolithiasis & 11.6 & 356 & + & + & 1 & RS & 5 & 21.7 \\
\hline Liang (2010) [25] & 59 & $\mathrm{~F}$ & $\begin{array}{c}\text { Mood changes, } \\
\text { lethargy }\end{array}$ & 12.3 & 371 & & + & 1 & RS & 4.5 & 13.3 \\
\hline $\begin{array}{l}\text { Burstein (2011) } \\
{[26]}\end{array}$ & 57 & $\mathrm{~F}$ & $\begin{array}{l}\text { Fatigue, brown } \\
\text { tumors }\end{array}$ & 15.9 & 1,905 & + & + & 1 & LI & 5 & 22 \\
\hline \multirow[t]{2}{*}{ Bai (2012) [27] } & 81 & M & & & 209 & - & + & 1 & RS & 4 & 6.91 \\
\hline & 55 & $\mathrm{M}$ & & & 150 & - & - & 1 & LS & 1.4 & 0.27 \\
\hline \multirow[t]{3}{*}{ Ezzat (2013) [9] } & 61 & $\mathrm{~F}$ & & 11.6 & 389 & + & + & 1 & LS & & 18 \\
\hline & 73 & M & & 13.0 & 290 & + & + & 1 & LI & 3.7 & 8 \\
\hline & 74 & $\mathrm{~F}$ & & 11.6 & 111 & + & - & 1 & LI & 1.6 & 0.9 \\
\hline $\begin{array}{l}\text { Papanicolau- } \\
\text { Sengos (2013) } \\
\text { [28] }\end{array}$ & 64 & M & & & & & & 1 & LI & 4.7 & \\
\hline $\begin{array}{l}\text { Piggott (2013) } \\
\text { [29] }\end{array}$ & 74 & F & $\begin{array}{c}\text { Abdominal pain, } \\
\text { lethargy }\end{array}$ & 12.5 & 489 & + & + & 1 & LI & 5.5 & 13 \\
\hline Chou (2014) [30] & 81 & $\mathrm{~F}$ & Pancreatitis & 12.0 & 450 & + & + & 1 & LS & 3.8 & \\
\hline $\begin{array}{l}\text { Murakami (2014) } \\
\text { [31] }\end{array}$ & 59 & $\mathrm{~F}$ & $\begin{array}{c}\text { Nephrolithiasis, } \\
\text { fracture, gastric } \\
\text { ulcer }\end{array}$ & 11.9 & 72 & + & - & 1 & LI & 0.8 & 0.5 \\
\hline $\begin{array}{l}\text { Tassone (2014) } \\
\text { [32] }\end{array}$ & 54 & $\mathrm{~F}$ & $\begin{array}{l}\text { Bone pain, } \\
\text { weakness }\end{array}$ & 12.4 & 130 & + & + & 1 & LI & 2.8 & \\
\hline Pirela (2016) [33] & 34 & $\mathrm{~F}$ & & 9.3 & & + & & 1 & IT(R) & 2.5 & \\
\hline $\begin{array}{l}\text { Boutzios (2017) } \\
{[34]}\end{array}$ & 53 & F & & 11.1 & 398 & + & + & 1 & LI & 5.4 & \\
\hline Yazar (2017) [20] & 47 & M & $\begin{array}{l}\text { Nephrolithiasis, } \\
\text { abdominal pain }\end{array}$ & 16.6 & 744 & + & - & 2 & RI LI & 2.5 & 2.8 \\
\hline $\begin{array}{l}\text { Ioannis (2018) } \\
\text { [35] }\end{array}$ & 58 & $\mathrm{~F}$ & & 10.4 & 902 & + & & 1 & $\mathrm{R}$ & 4.5 & 12 \\
\hline Arik (2019) [36] & 70 & M & Back pain & & & & & 1 & Mediastinum & 6 & \\
\hline \multirow[t]{2}{*}{$\begin{array}{l}\text { Radaideh (2019) } \\
\text { [37] }\end{array}$} & 50 & $\mathrm{~F}$ & $\begin{array}{l}\text { Pancreatitis, } \\
\text { osteoporosis }\end{array}$ & 12.1 & 429 & + & + & 1 & $\mathrm{R}$ & 5 & 36.3 \\
\hline & 33 & F & $\begin{array}{l}\text { Bone pain, } \\
\text { abdominal pain }\end{array}$ & 10.5 & 156 & + & - & 1 & LI & 1.2 & 0.3 \\
\hline $\begin{array}{l}\text { Zinovkin (2020) } \\
{[38]}\end{array}$ & 64 & $\mathrm{~F}$ & Osteopenia & 12.0 & 117 & & & 1 & LS & 3 & 5.34 \\
\hline $\begin{array}{l}\text { Mohamed (2021) } \\
\text { [39] }\end{array}$ & 56 & F & & 12.5 & 1.036 & + & + & 1 & LS & 3 & 9 \\
\hline \multirow[t]{6}{*}{ Juhlin (2021) [40] } & 53 & $\mathrm{~F}$ & & & 113 & + & - & 1 & LI & & 0.538 \\
\hline & 78 & $\mathrm{~F}$ & Nephrolithiasis & & 160 & + & - & 1 & RS & & 3.48 \\
\hline & 52 & $\mathrm{~F}$ & Muscle pain & & 85 & + & + & 1 & RI & & 0.47 \\
\hline & 38 & $\mathrm{~F}$ & Fatigue, depression & & 179 & + & & 1 & LI & & 1.34 \\
\hline & 61 & $\mathrm{~F}$ & $\begin{array}{l}\text { Osteopenia, } \\
\text { depression }\end{array}$ & & 123 & - & - & 1 & RI & & 0.883 \\
\hline & 58 & $\mathrm{~F}$ & $\begin{array}{c}\text { Osteopenia, } \\
\text { fatigue, muscle } \\
\text { pain }\end{array}$ & & 198 & + & & 1 & LS & & 0.577 \\
\hline Present case & 56 & M & $\begin{array}{c}\text { Nephrolithiasis, } \\
\text { osteoporosis }\end{array}$ & 12.7 & 937 & + & + & 2 & RI LI & 5.6 & 36.3 \\
\hline
\end{tabular}

a IT, intrathyroidal; LI, left inferior; LS, left superior; RI, right inferior; RS, right superior 


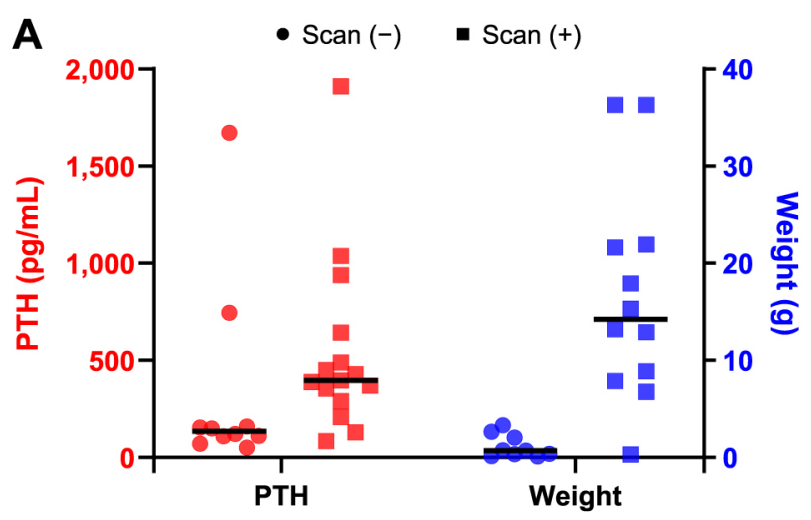

B
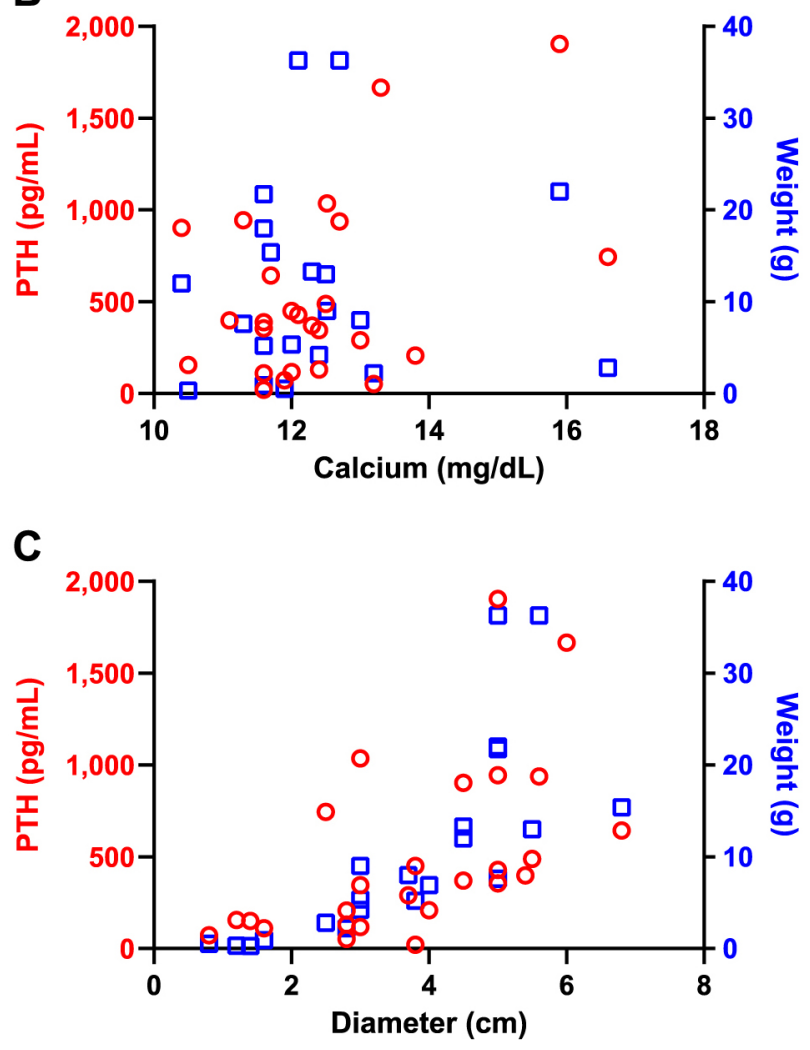

Fig. 3 Scatter plots of water-clear cell parathyroid adenomas reported in the literature. (A) PTH levels and adenoma weight grouped by negative or positive scintigraphy results. Black horizontal lines represent medians. (B) PTH levels and adenoma weight versus preoperative calcium levels. (C) PTH levels and adenoma weight versus maximum diameter of the adenoma.

hyperplastic [9]. The patient had normal calcium and PTH levels postoperatively, although only two parathyroids were resected. In all, 37 cases of water-clear cell parathyroid adenoma are presented in Table 1.

Despite controversy concerning the possibility of asymmetric hyperplasia, double adenoma has been considered a distinct clinical entity based on the observation that selective resection leads to a durable cure [10].
Interestingly, double adenomas seem to have a nonuniform anatomic distribution, namely, abnormal glands disproportionately involved in both sides of the neck [11]. Some authors propose that double adenoma may be an abnormal proliferation of embryologic origin (e.g., bilateral superior parathyroids arising from the fourth branchial pouch) rather than isolated neoplastic events. In our review, double water-clear cell adenoma occurred as a bilateral disease rather than a one-sided disease in all four patients. Intriguingly, in one case, both lesions were noted to be monoclonal using X-linked clonality analysis [12].

Water-clear cell hyperplasia has a reversed sex ratio with male predominance compared to chief cell hyperplasia $[4,13]$. It is suggested that water-clear cell hyperplasia may be etiologically different from the common form of primary hyperparathyroidism. Nonetheless, we found that water-clear cell adenomas had a 2:1 to $3: 1$ ratio of females to males. The most striking difference between the classic and water-clear cell adenomas was related to the size and weight of adenomas. For classic adenomas, tumor size commonly ranges from $1-3 \mathrm{~cm}$ and weight from 0.3-5 g [14]. Water-clear cell adenomas were remarkably larger and heavier. In addition, a positive correlation between the serum calcium and PTH levels is usually observed in patients with classic primary hyperparathyroidism [15]. The association unexpectedly disappeared in our pooled analysis of patients with water-clear cell adenomas.

Hyperplasia of water-clear parathyroid cells was shown to have low PTH levels in tissue extracts and high levels of circulating PTH, suggesting that PTH was excessively secreted and storage was markedly reduced [16]. Kanda et al. first speculated that water-clear cell parathyroid adenomas have low endocrine activity, and serum calcium concentration does not reach highly abnormal values until the adenoma is large enough [17]. Despite their enormous size, the malignancy of waterclear cell parathyroid tumors is exceptional. In a singular case, vascular invasion was the only malignant feature [18]. It is noteworthy that although serum calcium levels are not proportional to the large tumor burden, waterclear cell adenomas are not free of adverse consequences. We found that renal and skeletal complications were common in patients with water-clear cell adenomas. Considering the low proliferative activity of these tumors, it is likely that a long latent period elapses before the symptoms become clinically apparent.

Given the relatively large tumor size, visualization of lesions on ultrasonography is not difficult. However, water-clear cell adenomas are frequently isoechoic, as in our patient, which makes them sometimes indistinguishable from thyroid nodules [19]. Previous studies have 
Table 2 Comparison of characteristics between water-clear cell adenomas and classic adenomas in patients with primary hyperparathyroidism ( $\mathrm{pHPT})$

\begin{tabular}{|c|c|c|c|c|c|c|c|c|c|c|c|}
\hline $\begin{array}{l}\text { First author } \\
\text { (year) }\end{array}$ & Type & $n$ & $\begin{array}{l}\text { Age } \\
\text { (year) }\end{array}$ & Sex (M:F) & Presentations & $\begin{array}{l}\text { Calcium } \\
(\mathrm{mg} / \mathrm{dL})\end{array}$ & $\begin{array}{c}\text { PTH } \\
(\mathrm{pg} / \mathrm{mL})\end{array}$ & Ultrasound & Scintigraphy & $\begin{array}{l}\text { Diameter } \\
(\mathrm{cm})\end{array}$ & $\begin{array}{l}\text { Weight } \\
(\mathrm{g})\end{array}$ \\
\hline $\begin{array}{l}\text { Roizen } \\
(2014)[41]\end{array}$ & $\begin{array}{l}\text { pHPT (12\% } \\
\text { hyperplasia) }\end{array}$ & 2,405 & & & & 11.2 & 174.5 & & & & 1.19 \\
\hline \multirow[t]{2}{*}{$\begin{array}{l}\text { Howson } \\
(2015)[42]\end{array}$} & Non-oxyphilic & 91 & 66.5 & $\begin{array}{l}72: 19 \\
(3.8: 1)\end{array}$ & $\begin{array}{l}3 \% \text { nephrolithiasis } \\
48 \% \text { osteoporosis }\end{array}$ & 10.44 & 63.94 & $63 \%$ & $66 \%$ & & \\
\hline & Oxyphilic & 91 & 66.6 & $\begin{array}{l}72: 19 \\
(3.8: 1)\end{array}$ & $\begin{array}{c}10 \% \text { nephrolithiasis } \\
41 \% \text { osteoporosis }\end{array}$ & 10.8 & 138.59 & $47 \%$ & $54 \%$ & & \\
\hline $\begin{array}{l}\text { Stern (2016) } \\
{[6]}\end{array}$ & Single adenoma & 378 & 63.4 & $\begin{array}{l}287: 91 \\
(3.2: 1)\end{array}$ & $\begin{array}{c}21 \% \text { nephrolithiasis } \\
40 \% \text { osteoporosis }\end{array}$ & 11.5 & 165 & & & 1.8 & 1.4 \\
\hline $\begin{array}{l}\text { Nafisi (2017) } \\
{[43]}\end{array}$ & Adenoma & 1,137 & 57.5 & $\begin{array}{l}836: 301 \\
(2.8: 1)\end{array}$ & & & & $80 \%$ & $84 \%$ & & \\
\hline $\begin{array}{l}\operatorname{Lam}(2019) \\
{[15]}\end{array}$ & $\begin{array}{l}\text { pHPT (13\% } \\
\text { hyperplasia) }\end{array}$ & 95 & 59 & $\begin{array}{l}72: 23 \\
(3.1: 1)\end{array}$ & $\begin{array}{c}34 \% \text { nephrolithiasis } \\
5 \% \text { fracture }\end{array}$ & 11.4 & 148 & & & & 0.586 \\
\hline $\begin{array}{l}\text { Zafereo } \\
(2019) \text { [44] }\end{array}$ & pHPT (review) & & & & & & & $74-91 \%$ & $70-86 \%$ & & \\
\hline Present study & $\begin{array}{l}\text { Water-clear cell } \\
\text { adenoma }\end{array}$ & 37 & 56 & $\begin{array}{l}27: 10 \\
(2.7: 1)\end{array}$ & $\begin{array}{c}24 \% \text { nephrolithiasis } \\
27 \% \text { bone } \\
\text { complications }\end{array}$ & 12.0 & 290 & $89 \%$ & $60 \%$ & 3.8 & 5.27 \\
\hline
\end{tabular}

Note: estimates are mean or median values.

suggested decreased sensitivity of preoperative scintigraphic localization [20], probably due to the low content of mitochondria in water-clear cells and the paucity of oxyphilic cells. Overall, our analysis showed that nearly two-thirds of the patients were positive for sestamibi scintigraphy. A comparison between the characteristics of water-clear cell adenomas and those of the classic adenomas reported in recent series or reviews is compiled in Table 2.

In summary, we report a rare case of double waterclear cell parathyroid adenoma that was successfully treated by surgery without residual hyperparathyroidism. A review of the literature reveals several notable features of water-clear cell adenomas, including large tumor size, relatively indolent biochemical profile, high prevalence of complications and nonspecific symptoms, an isoechoic appearance on ultrasonography, and reduced scintigraphic sensitivity.

\section{Acknowledgements}

The study was reviewed and approved by the Institutional Review Board (21MMHIS286e) and was conducted in accordance with the Declaration of Helsinki. The publication of this study was supported by a grant (MOST-110-2314-B-195-018-MY3) from the Ministry of Science and Technology of Taiwan. The funders had no role in study design, data collection and analysis, decision to publish, or preparation of the manuscript.

\section{Disclosure Statement}

The authors have no potential conflicts of interest.

\section{References}

1. Walker MD, Silverberg SJ (2018) Primary hyperparathyroidism. Nat Rev Endocrinol 14: 115-125.

2. Duan K, Gomez Hernandez K, Mete O (2015) Clinicopathological correlates of hyperparathyroidism. J Clin Pathol 68: 771-787.

3. El Hussein S, Poppiti R (2017) Water clear cell adenoma of the parathyroid gland: a forgotten cause of primary hyperparathyroidism. Int J Surg Pathol 25: 384-388.

4. Castleman B, Schantz A, Roth S (1976) Parathyroid hyperplasia in primary hyperparathyroidism: a review of
85 cases. Cancer 38: $1668-1675$.

5. Varshney S, Bhadada SK, Nahar U, Shah VN, Bhansali A, et al. (2013) Chief cell and clear cell parathyroid adenoma do not influence clinical and biochemical expression of the sporadic primary hyperparathyroidism. Endocrine 43 : 440-443.

6. Stern S, Mizrachi A, Strenov Y, Knaanie A, Benbassat C, et al. (2017) Parathyroid adenoma: a comprehensive biochemical and histological correlative study. Clin Otolaryngol 42: 381-386. 
7. Kovacs K, Horvath E, Ozawa Y, Yamada S, Matushita H (1994) Large clear cell adenoma of the parathyroid in a patient with MEN-1 syndrome. Ultrastructural study of the tumour exhibiting unusual RER formations. Acta Biol Hung 45: 275-284.

8. Stout LC Jr (1985) Water-clear-cell hyperplasia mimicking parathyroid adenoma. Hum Pathol 16: 1075-1076.

9. Ezzat T, Maclean GM, Parameswaran R, Phillips B, Komar V, et al. (2013) Primary hyperparathyroidism with water clear cell content: the impact of histological diagnosis on clinical management and outcome. Ann R Coll Surg Engl 95: e60-e62.

10. Tezelman S, Shen W, Shaver JK, Siperstein AE, Duh QY, et al. (1993) Double parathyroid adenomas. Clinical and biochemical characteristics before and after parathyroidectomy. Ann Surg 218: 300-307; discussion 307-309.

11. Bergson EJ, Heller KS (2004) The clinical significance and anatomic distribution of parathyroid double adenomas. J Am Coll Surg 198: 185-189.

12. Kuhel WI, Gonzales D, Hoda SA, Pan L, Chiu A, et al. (2001) Synchronous water-clear cell double parathyroid adenomas a hitherto uncharacterized entity? Arch Pathol Lab Med 125: 256-259.

13. Tisell LE, Hedman I, Hansson G (1981) Clinical characteristics and surgical results in hyperparathyroidism caused by water-clear cell hyperplasia. World J Surg 5: 565-571.

14. Fraser WD (2009) Hyperparathyroidism. Lancet 374: $145-158$.

15. Lam HB, Yang PS, Chien MN, Lee JJ, Chao LF, et al. (2019) Association between neutrophil-to-lymphocyte ratio and parathyroid hormone in patients with primary hyperparathyroidism. Arch Med Sci 15: 880-886.

16. Dawkins RL, Tashjian AH Jr, Castleman B, Moore EW (1973) Hyperparathyroidism due to clear cell hyperplasia. Serial determinations of serum ionized calcium, parathyroid hormone and calcitonin. Am J Med 54: 119-126.

17. Kanda K, Okada Y, Tanikawa T, Morita E, Tsurudome Y, et al. (2004) A rare case of primary hyperparathyroidism with clear cell adenoma. Endocr J 51: 207-212.

18. Naganuma H, Shibuya R, Takaya K, Asakura T, Mori Y, et al. (2013) Water-clear cell carcinoma of parathyroid gland with primary hyperparathyroidism: first case report with review of the literature. J Basic Clin Med 2: 7-9.

19. Kodama H, Iihara M, Okamoto T, Obara T (2007) Waterclear cell parathyroid adenoma causing primary hyperparathyroidism in a patient with neurofibromatosis type 1 : report of a case. Surg Today 37: 884-887.

20. Yazar FM, Karaagac M, Isler A, Bulbuloglu E, Ezberci F (2017) An unusual cause of hypercalcemic crisis: waterclear cell double parathyroid adenoma. Turk J Surg 33: 243-247.

21. Grenko RT, Anderson KM, Kauffman G, Abt AB (1995) Water-clear cell adenoma of the parathyroid. A case report with immunohistochemistry and electron microscopy. Arch Pathol Lab Med 119: 1072-1074.

22. Begueret H, Belleannee G, Dubrez J, Trouette H, Parrens
M, et al. (1999) Clear cell adenoma of the parathyroid gland: a rare and misleading lesion. Ann Pathol 19: 316319 (In French).

23. Dundar E, Grenko RT, Akalin A, Karahuseyinoglu E, Bildirici K (2001) Intrathyroidal water-clear cell parathyroid adenoma: a case report. Hum Pathol 32: 889-892.

24. Prasad KK, Agarwal G, Krishnani N (2004) Water-clear cell adenoma of the parathyroid gland: a rare entity. Indian J Pathol Microbiol 47: 39-40.

25. Liang Y, Mojica W, Chen F (2010) Water-clear cell adenoma of parathyroid gland: a case report and literature review. N Am J Med Sci 3: 194-198.

26. Burstein DH, Parmar PS (2011) Water-clear cell adenoma mimicking parathyroid carcinoma. Laryngoscope 121: S97.

27. Bai S, LiVolsi VA, Fraker DL, Bing Z (2012) Water-clear parathyroid adenoma: report of two cases and literature review. Endocr Pathol 23: 196-200.

28. Papanicolau-Sengos A, Brumund K, Lin G, Hasteh F (2013) Cytologic findings of a clear cell parathyroid lesion. Diagn Cytopathol 41: 725-728.

29. Piggott RP, Waters PS, Ashraf J, Colesky F, Kerin MJ (2013) Water-clear cell adenoma: a rare form of hyperparathyroidism. Int J Surg Case Rep 4: 911-913.

30. Chou YH, Jhuang JY, Hsieh MS (2014) Water-clear cell parathyroid adenoma in a patient with acute pancreatitis. $J$ Formos Med Assoc 113: 872-873.

31. Murakami K, Watanabe M, Nakashima N, Fujimori K, Ishida $\mathrm{K}$, et al. (2014) Water-clear cell adenoma associated with primary hyperparathyroidism: report of a case. Surg Today 44: 773-777.

32. Tassone P, Kaplan S, Kenyon L, Rosen D, Pribitkin E (2014) Water clear cell parathyroid adenoma: case report and literature review. Thyroid Disorders Ther 3: 3.

33. Pirela D, Treitl D, El Hussein S, Poppiti R, Mesko T, et al. (2016) Intrathyroidal clear cell tumor of parathyroid origin with review of literature. Case Rep Pathol 2016: 7169564.

34. Boutzios G, Sarlanis H, Kolindou A, Velidaki A, Karatzas T (2017) Primary hyperparathyroidism caused by enormous unilateral water-clear cell parathyroid hyperplasia. BMC Endocr Disord 17: 57.

35. Ioannis P, Stavros P, Nektarios K, Chrysa S, Kalliopi P, et al. (2018) Water-clear cell adenoma of parathyroid gland: a case report and concerns on differential diagnosis. $J$ Endocrinol Diabetes Obes 6: 1117.

36. Arik D, Dundar E, Yilmaz E, Sivrikoz C (2019) Waterclear cell adenoma of the mediastinal parathyroid gland. Turk Patoloji Derg 35: 157-161.

37. Radaideh AM, Alkhalidi H, Nusier M, Alqudah M (2019) Water clear cell parathyroid adenoma: a report of two cases. AGJSR 37: 33-42.

38. Zinovkin DA, Zhandarov MY, Pranjol MZI (2020) Water clear cell adenoma of parathyroid gland: a rare lesion. Exp Oncol 42: 248.

39. Mohamed W, El Ansari W, Al Hassan MS, Sibira RM, Abusabeib A (2021) Water clear cell ectopic noniatrogenic giant parathyroid adenoma in sternohyoid 
muscle with thyroid nodule and asymptomatic hypercalcemia due to primary hyperparathyroidism: case report and literature review. Int J Surg Case Rep 86: 106295.

40. Juhlin CC, Nilsson IL, Falhammar H, Zedenius J (2021) Institutional characterisation of water clear cell parathyroid adenoma: a rare entity often unrecognised by Tc-99m-sestamibi scintigraphy. Pathology 53: 852-859.

41. Roizen J, Levine MA (2014) A meta-analysis comparing the biochemistry of primary hyperparathyroidism in youths to the biochemistry of primary hyperparathyroidism in adults. J Clin Endocrinol Metab 99: 4555-4564.

42. Howson P, Kruijff S, Aniss A, Pennington T, Gill AJ, et al. (2015) Oxyphil cell parathyroid adenomas causing primary hyperparathyroidism: a clinico-pathological cor- relation. Endocr Pathol 26: 250-254.

43. Nafisi Moghadam R, Amlelshahbaz AP, Namiranian N, Sobhan-Ardekani M, Emami-Meybodi M, et al. (2017) Comparative diagnostic performance of ultrasonography and $99 \mathrm{mTc}$-sestamibi scintigraphy for parathyroid adenoma in primary hyperparathyroidism; systematic review and meta-analysis. Asian Pac J Cancer Prev 18: 31953200 .

44. Zafereo M, Yu J, Angelos P, Brumund K, Chuang HH, et al. (2019) American Head and Neck Society Endocrine Surgery Section update on parathyroid imaging for surgical candidates with primary hyperparathyroidism. Head Neck 41: 2398-2409. 